\title{
Identification of genetic alterations in pancreatic cancer by the combined use of tissue microdissection and array-based
} comparative genomic hybridisation

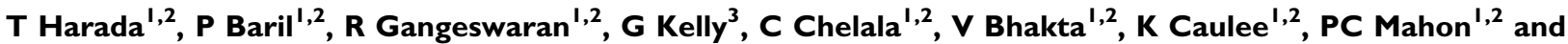 \\ NR Lemoine*,1,2
}

'Centre for Molecular Oncology, Institute of Cancer, Barts and The London School of Medicine and Dentistry, Queen Mary University of London, Charterhouse Square, London ECIM 6BQ, UK; ${ }^{2}$ Cancer Research UK Clinical Centre, Barts and The London School of Medicine and Dentistry, Queen Mary University of London, Charterhouse Square, London ECIM 6BQ, UK; ${ }^{3}$ Cancer Research UK, Bioinformatics and Biostatistics Service, Lincoln's Inn Fields, London WC2A 3PX, UK

\begin{abstract}
Pancreatic ductal adenocarcinoma (PDAC) is characterised pathologically by a marked desmoplastic stromal reaction that significantly reduces the sensitivity and specificity of cytogenetic analysis. To identify genetic alterations that reflect the characteristics of the tumour in vivo, we screened a total of 23 microdissected PDAC tissue samples using array-based comparative genomic hybridisation (array $\mathrm{CGH}$ ) with I Mb resolution. Highly stringent statistical analysis enabled us to define the regions of nonrandom genomic changes. We detected a total of $4 \mathrm{I}$ contiguous regions $(>3.0 \mathrm{Mb}$ ) of copy number changes, such as a genetic gain at $7 \mathrm{p} 22.2-\mathrm{p} 15.1$

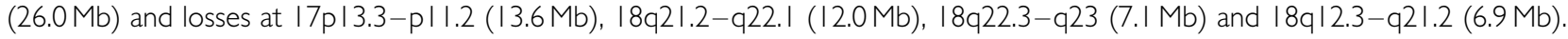
To validate our array $\mathrm{CGH}$ results, fluorescence in situ hybridisation was performed using four probes from those regions, showing that these genetic alterations were observed in 37-68\% of a separate sample set of 19 PDAC cases. In particular, deletion of the SECI I L3 gene ( I 8q21.32) was detected at a very high frequency (I 3 out of 19 cases; 68\%) and in situ RNA hybridisation for this gene demonstrated a significant correlation between deletion and expression levels. It was further confirmed by reverse transcriptionPCR that SECI IL3 mRNA was downregulated in 16 out of 16 PDAC tissues (100\%). In conclusion, the combination of tissue microdissection and array $\mathrm{CGH}$ provided a valid data set that represents in vivo genetic changes in PDAC. Our results raise the possibility that the SECI I L3 gene may play a role as a tumour suppressor in this disease.

British Journal of Cancer (2007) 96, 373-382. doi:I0.1038/sj.bjc.6603563 www.bjcancer.com
\end{abstract}

(C) 2007 Cancer Research UK

Keywords: pancreatic cancer; tissue microdissection; array CGH; SECI IL3

Pancreatic ductal adenocarcinoma (PDAC) is the fourth leading cause of cancer-related death in Western countries. Although the prognosis of patients with many types of cancer has improved recently due to advances in diagnostic and therapeutic modalities, the outlook for patients with PDAC still remains dismal with a median survival of just 6 months from diagnosis and an overall 5year survival rate of less than 5\% (Warshaw and Fernandez-del Castillo, 1992; Murr et al, 1994; Jemal et al, 2005). Many previous studies have attempted to elucidate the molecular mechanisms underlying pancreatic tumorigenesis, but it is still not fully understood. Therefore, a better understanding of the genes involved in tumour growth and progression is necessary for the development of novel diagnostic and therapeutic strategies that could improve the outcome of this deadly disease.

Array-based comparative genomic hybridisation (array CGH) is a powerful technique that has been used to detect DNA copy

\footnotetext{
*Correspondence: Professor NR Lemoine;

E-mail: nick.lemoine@cancer.org.uk

Received 6 September 2006; revised 16 November 2006; accepted 27 November 2006
}

number alterations across the entire genome of malignant tumours (Solinas-Toldo et al, 1997; Pinkel et al, 1998; Pollack et al, 1999; Albertson et al, 2000; Snijders et al, 2001; Fiegler et al, 2003). Compared to conventional $\mathrm{CGH}$, the significantly improved resolution of array CGH permits highly accurate mapping of DNA copy number changes throughout the genome. In cancer, genomic alterations contribute to dysregulation of the expression levels of oncogenes and tumour suppressor genes, the accumulation of which is correlated with tumour progression (Ried et al, 1999). Therefore, array CGH provides a promising starting point for the identification of novel candidate genes affected by such genomic imbalances. Several array CGH investigations of PDAC have already been reported, but all these studies were performed on cell lines or whole tissue samples (Aguirre et al, 2004; Heidenblad et al, 2004; Holzmann et al, 2004; Mahlamaki et al, 2004; Bashyam et al, 2005; Gysin et al, 2005; Nowak et al, 2005). In cell lines, culture-induced genetic adaptation may be induced during the establishment of cell lines in in vitro conditions. On the other hand, PDAC tissues are characterised by a desmoplastic reaction, with neoplastic cells constituting only a small proportion of the tumour mass. Therefore, cytogenetic analysis using bulk tissue samples is invariably hampered by contamination with nonneoplastic cells. 
The aim of this study is to identify novel genetic abnormalities that precisely reflect the characteristics of tumour cells in vivo. For this purpose, we applied array CGH to 23 microdissected PDAC tissue samples that consist of purified populations of cancer cells. Then, a subset of identified genetic alterations was evaluated in an independent sample set of 19 PDAC cases using fluorescence in situ hybridisation (FISH) analysis. Finally, in situ RNA hybridisation (ISH) and reverse transcription-PCR (RT-PCR) were performed to assess whether the identified genetic alteration could lead to significant change in transcript level of the gene in question.

\section{MATERIALS AND METHODS}

\section{Tissue samples}

A total of 23 fresh-frozen PDAC specimens were obtained surgically or at autopsy from Yamaguchi University School of
Medicine, Japan, with appropriate ethical approval (Table 1). All the tissues were confirmed histologically by a pathologist. Tissue microdissection was performed manually to collect more than $90 \%$ of tumour cells in all the cases as described previously (Harada et al, 2002a). Briefly, only cancerous regions were microdissected using a sterile 26-gauge needle from several serial tissue sections (20 $\mu \mathrm{m}$ thickness) under visualisation with an inverted microscope (Nikon 66906, Tokyo, Japan). DNA was extracted from at least 5000 tumour cells according to the standard protocol. Reference DNA was obtained from lymphocytes of both healthy male and female volunteers. In addition, another series of 19 formalin-fixed, paraffin-embedded tumour sections ( $4 \mu \mathrm{m}$ thickness) were provided from Yamaguchi University $(n=10)$ and Tohoku University School of Medicine, Japan $(n=9)$, for FISH and ISH analyses (Table 1). Owing to the limited accessibility of clinical specimens, the samples used in array CGH were not available for FISH and ISH. For RT-PCR, 16 fresh-frozen PDAC tissues and two normal pancreas tissues were obtained from the Human Biomaterials Resource Centre, Department of Histopathology, Charing Cross

Table I The clinicopathological data of PDAC tissue samples

\begin{tabular}{|c|c|c|c|c|c|c|c|c|}
\hline Sample & Age & Sex & Location $^{\mathbf{a}}$ & Histology $^{\mathrm{b}}$ & $\mathbf{T}$ & $\mathbf{N}$ & $M$ & Stage \\
\hline $\mathrm{PCl}$ & 66 & $\mathrm{~F}$ & $\mathrm{P}(\mathrm{Ph})$ & $\bmod$ & 3 & 0 & 0 & $\|$ \\
\hline PC3 & 66 & $M$ & $\mathrm{P}(\mathrm{Ph})$ & mod & 3 & $\mathrm{lb}$ & 0 & III \\
\hline PC4 & 59 & $\mathrm{~F}$ & $\mathrm{P}(\mathrm{Ph})$ & mod & 3 & $\mathrm{Ib}$ & 0 & III \\
\hline PC5 & 64 & M & $\mathrm{P}(\mathrm{Ph})$ & $\bmod$ & 3 & $\mathrm{Ib}$ & 0 & III \\
\hline PC6 & 47 & $M$ & $\mathrm{P}(\mathrm{Ph})$ & mod & 4 & Ib & 0 & $\mathrm{IVa}$ \\
\hline PC9 & 73 & $\mathrm{~F}$ & $\mathrm{P}(\mathrm{Ph})$ & mod & 4 & Ib & 0 & $\mathrm{IVa}$ \\
\hline $\mathrm{PCIO}$ & 56 & M & $P(P t)$ & $\bmod$ & 4 & $\mathrm{lb}$ & | & $\mathrm{IVb}$ \\
\hline $\mathrm{PCl} I$ & 76 & $\mathrm{~F}$ & $\mathrm{P}(\mathrm{Ph})$ & mod & 4 & lb & | & $\mathrm{IVb}$ \\
\hline $\mathrm{PCl} 2$ & 63 & $\mathrm{~F}$ & $\mathrm{P}(\mathrm{Pb})$ & mod & 4 & lb & 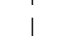 & $\mathrm{IVb}$ \\
\hline $\mathrm{PCl} 3$ & 78 & $\mathrm{~F}$ & $P(P t)$ & $\bmod$ & 4 & $1 \mathrm{~b}$ & 1 & $\mathrm{IVb}$ \\
\hline $\mathrm{PCl} 4$ & 68 & $\mathrm{~F}$ & $\mathrm{P}(\mathrm{Ph})$ & $\bmod$ & 4 & lb & i & $\mathrm{IVb}$ \\
\hline $\mathrm{PCI} 5$ & 65 & $M$ & $\mathrm{P}(\mathrm{Pb})$ & mod & 4 & lb & 1 & $\mathrm{IVb}$ \\
\hline PC34 & 60 & $M$ & LM & mod & 4 & lb & i & $\mathrm{IVb}$ \\
\hline PC35 & 75 & M & LM & $\bmod$ & 4 & Ib & 1 & $\mathrm{IVb}$ \\
\hline PC36 & 67 & $\mathrm{~F}$ & LM & $\bmod$ & 4 & lb & 1 & $\mathrm{IVb}$ \\
\hline \multicolumn{9}{|c|}{ (B) Formalin-fixed, paraffin-embedded tissue sections used for FISH and ISH $(n=19)$} \\
\hline PC37 & 74 & M & $\mathrm{P}(\mathrm{Ph})$ & $\bmod$ & 2 & 0 & 0 & । \\
\hline PC38 & 72 & M & $\mathrm{P}(\mathrm{Pt})$ & poor & 3 & 0 & 0 & $\|$ \\
\hline PC39 & 70 & M & $\mathrm{P}(\mathrm{Ph})$ & mod & 3 & । & 0 & III \\
\hline PC40 & 58 & M & $\mathrm{P}(\mathrm{Ph})$ & $\bmod$ & 3 & i & 0 & III \\
\hline PC4I & 69 & $\mathrm{~F}$ & $\mathrm{P}(\mathrm{Pb})$ & well & 3 & 1 & 0 & III \\
\hline PC42 & 51 & $M$ & $\mathrm{P}(\mathrm{Ph})$ & poor & 3 & i & 0 & III \\
\hline PC43 & 73 & M & $\mathrm{P}(\mathrm{Ph})$ & $\bmod$ & 3 & 1 & 0 & III \\
\hline PC44 & 59 & $M$ & $\mathrm{P}(\mathrm{Pb})$ & mod & 3 & I & 0 & III \\
\hline PC55 & 74 & M & LM & poor & 4 & 1 & 1 & $\mathrm{IVb}$ \\
\hline
\end{tabular}

${ }^{a} \mathrm{P}=$ primary lesion; $\mathrm{Ph}=$ head; $\mathrm{Pb}=$ body; $\mathrm{Pt}=$ tail of the pancreas; $\mathrm{LM}=$ liver metastatic lesion. ${ }^{\mathrm{b}} \mathrm{mod}=$ moderately; poor $=$ poorly differentiated tubular adenocarcinoma. PDAC = pancreatic ductal adenocarcinoma; FISH = fluorescence in situ hybridisation; ISH = in situ RNA hybridisation. 
Hospital, London, UK, with full ethical approval of the host institution. The clinicopathological information was not available for these anonymous samples. Haematoxylin-eosin-stained slides were examined to ensure a content of $60-80 \%$ tumour cells before use and then, total RNA was extracted directly from homogenised tissues using TRIZOL (Invitrogen Ltd, Paisley, UK).

\section{CGH arrays and image acquisition}

The whole-genome CGH arrays were produced at the Wellcome Trust Sanger Institute and consist of 3125 BAC/PAC clones that cover the entire human genome at $1 \mathrm{Mb}$ resolution (Fiegler et al, 2003). All the clone details are available on the Ensembl genome browser (v39, June 2006; http://www.ensembl.org/Homo_sapiens/ index.html).

Array CGH was performed as described previously, with minor modifications (Fiegler et al, 2003; Hurst et al, 2004). Briefly, tumour and reference DNAs (300 ng) were labelled with Cy5-dCTP and Cy3-dCTP, respectively. Hybridisation was carried out at $37^{\circ} \mathrm{C}$ for $36 \mathrm{~h}$ in a hybridisation chamber (GeneMachines, San Carlos, CA, USA). After washing the slides, fluorescence intensities were measured on an Axon 4000B scanner (Axon Instruments Inc., Burlingame, CA, USA) and the raw images were analysed using the GenePix Pro 4.0 software (Axon). Duplicate hybridisations were performed for each sample to verify the reproducibility of the data except for one case (PC5). The correlation coefficients were calculated on the normalised tumour channel and observed to range from 0.63 to 0.90 (data not shown).

\section{Statistical and data analysis}

The CGH arrays were read with the UCSF 'SPOT' software to produce raw text files (Jain et al, 2002). These files were read into R and normalised (using the loess intensity-dependent method), using the 'limma' package (Smyth, 2005; The R Development Core Team, 2006); background correction was omitted in this case, as visual inspection showed it increased the scatter in both the MA and chromosomal-location plots, and the correlation statistics were worse with background subtraction, indicative of low levels of background on the slides being misestimated. The $\log _{2}$-transformed normalised data were then pre-processed to average any on-slide replicates using the 'snapCGH' package from Bioconductor and segmented into local regions of constant copy number by circular binary segmentation (Gentleman et al, 2004; Olshen et al, 2004). The sample levels (two replicates for each tumour per clone) were summarised by means to give tumour-level data (one measurement per clone for each tumour). These data were then used in a linear model that estimated the fold change across the tumours, along with a $P$-value that the average $\log _{2}$-fold change between the tumour channel and the normal channel was non-zero (for both the normalised data and the locally smoothed data - data not shown for the latter). Clones that had an uncorrected $P$-value below 0.001 were considered to be significant candidates.

\section{Two-colour FISH}

Four human BAC clones (RP11-403N12, RP11-232C20, RP11-8H2 and RP11-350K6) were purchased from BACPAC Resources (Oakland, CA, USA) and these DNAs were labelled with Cy3dCTP using BioPrime Array CGH Genomic Labeling System (Invitrogen). Centromeric probes for chromosomes 7 and 18 (CEP7 and 18), labelled with SpectrumGreen, were purchased from Vysis (Downers Grove, IL, USA). The specificity of all the probes was confirmed by hybridisation onto Normal Male Metaphase (Vysis).

Two-colour FISH was performed as described previously (Lu et al, 1999). DNA copy number was evaluated for each probe by counting spots in at least 100 nuclei. A ratio was calculated between the average copy number of the BAC probes and of corresponding centromeric probes. Based on hybridisation in 10 normal pancreatic tissues (acinar and ductal cells), the threshold of gain and loss was defined as the ratios of $>1.16(+2$ standard deviation (s.d.)) and $<0.87$ ( -2 s.d.), respectively (data not shown). Our approach was to use normal samples to estimate overall noise levels: choosing the threshold on the tumour samples corresponding to $a \pm 2$ s.d. of the normal samples indicates a roughly $5 \%$ false-positive rate if the tumour samples were commensurate with diploidy.

\section{In situ RNA hybridisation for SEC11L3}

The SEC11L3 probe was amplified by PCR from OriGene clone TC123085 (OriGene Technologies, Inc., Rockville, MD, USA) that encodes full-length cDNA of SEC11L3. The primers used to amplify a 216-bp SEC11L3 product are as follows: forward 5'-TTGGATA TCTTCGGGGACCT- $3^{\prime}$ and reverse $5^{\prime}$-GTCTTCCCGGAAATTTGT GA-3'. The PCR product was cloned into the pCR4-TOPO vector using the TOPO cloning kit (Invitrogen) to create pCR4-SEC11L3ISH. Positive clones were verified by sequence analysis. The pCR4SEC11L3-ISH plasmid was linearised with PstI for the sense probe and NotI for the antisense probe. After removing restriction endonucleases, riboprobes were synthesised from $1 \mu \mathrm{g}$ of template DNA and digoxigenin (DIG) were labelled using a DIG RNA labeling kit (Roche Diagnostics GmbH, Mannheim, Germany). T3 and T7 polymerases were used to synthesise antisense probes and sense probes, respectively. DIG incorporation of riboprobes was verified by DOT blot with anti-digoxigenin-AP Fab fragments (Roche). Antisense and sense riboprobes for SEC11L3 were hybridised to 19 tissue sections using the Ventana Discovery System with Ventana Ribomap and Bluemap kits. Expression of SEC11L3 mRNA in cancer cells was compared to that of nonneoplastic epithelial cells (ductal, acinar, intestinal and hepatic cells) on the identical specimen and judged using a 0-2 score $(0=$ no staining, $1=$ weak intensity, $2=$ intensity comparable to non-neoplastic counterparts).

\section{Reverse transcription-PCR for SEC11L3}

cDNAs were synthesised from $1 \mu \mathrm{g}$ of total RNA using an oligo dT primer and the Multiscribe reverse transcription kit (Applied Biosystems, Warrington, Cheshire, UK) as instructed by the manufacturer. Reverse transcription was followed by 30 PCR cycles ( $1 \mathrm{~min}$ of denaturation at $94^{\circ} \mathrm{C}, 1 \mathrm{~min}$ of annealing at $55^{\circ} \mathrm{C}$ and 1 min of extension at $72^{\circ} \mathrm{C}$ ). Primers for SEC11L3 are the same as those designed in ISH. Primers for $18 \mathrm{~S}$ ribosomal RNA, which was used as an endogenous control for normalisation, are as follows: forward $5^{\prime}$-CGCCGCTAGAGGTGAAATTC- $3^{\prime}$ and reverse $5^{\prime}$-CATTCTTGGCAAATGCTTTCG-3'. Amplified products were separated on $1 \%$ agarose gels and visualised with ethidium bromide.

\section{RESULTS}

\section{Comparison of array CGH profiles in microdissected tissues and cell lines}

A total of 23 microdissected PDAC tissues were analysed by array CGH. Applying highly stringent statistical conditions $(P<0.001)$, we could identify the regions of nonrandom genomic changes in PDAC. Figure 1 shows overall copy number changes for each chromosome and the entire data set of all clones is available in Supplementary Table 1 (the raw data set for all the experiments is shown in Supplementary Table 2). A total of 1015 clones met the statistical criterion; $17 \%$ of clones (508 clones including 698 candidate genes) showed genetic gain and $17 \%$ (507 clones including 1254 genes) showed loss. The array CGH profiles were 

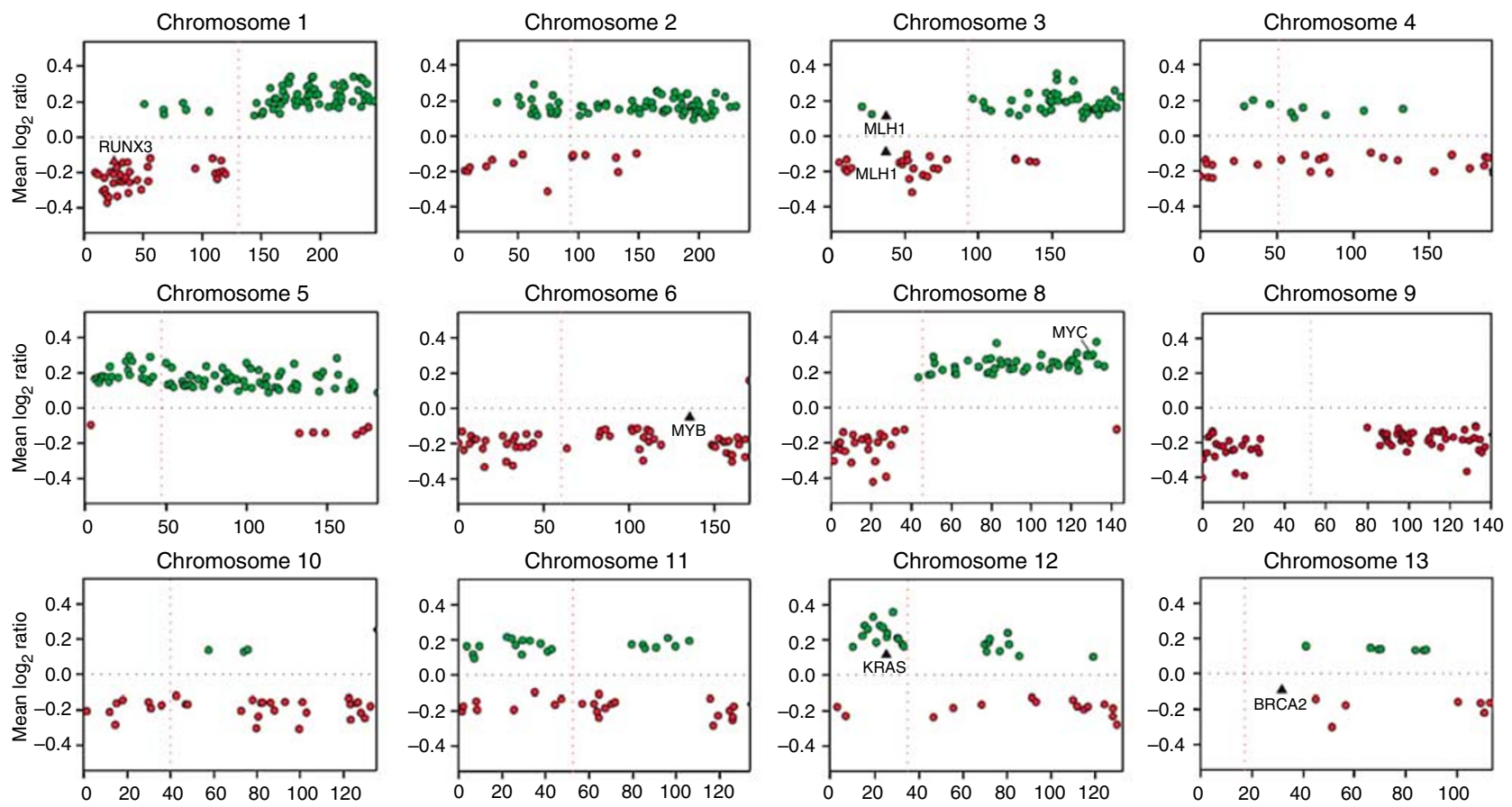

Chromosome 11

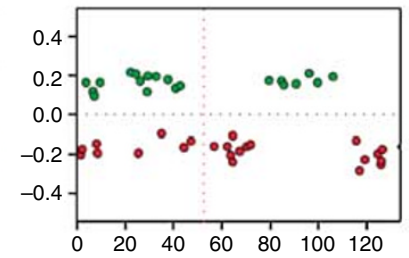

Chromosome 12

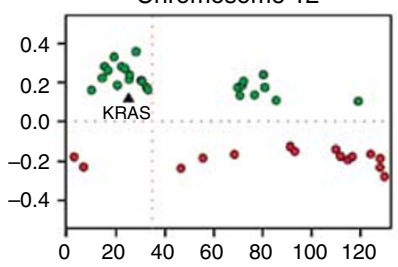

Chromosome 13
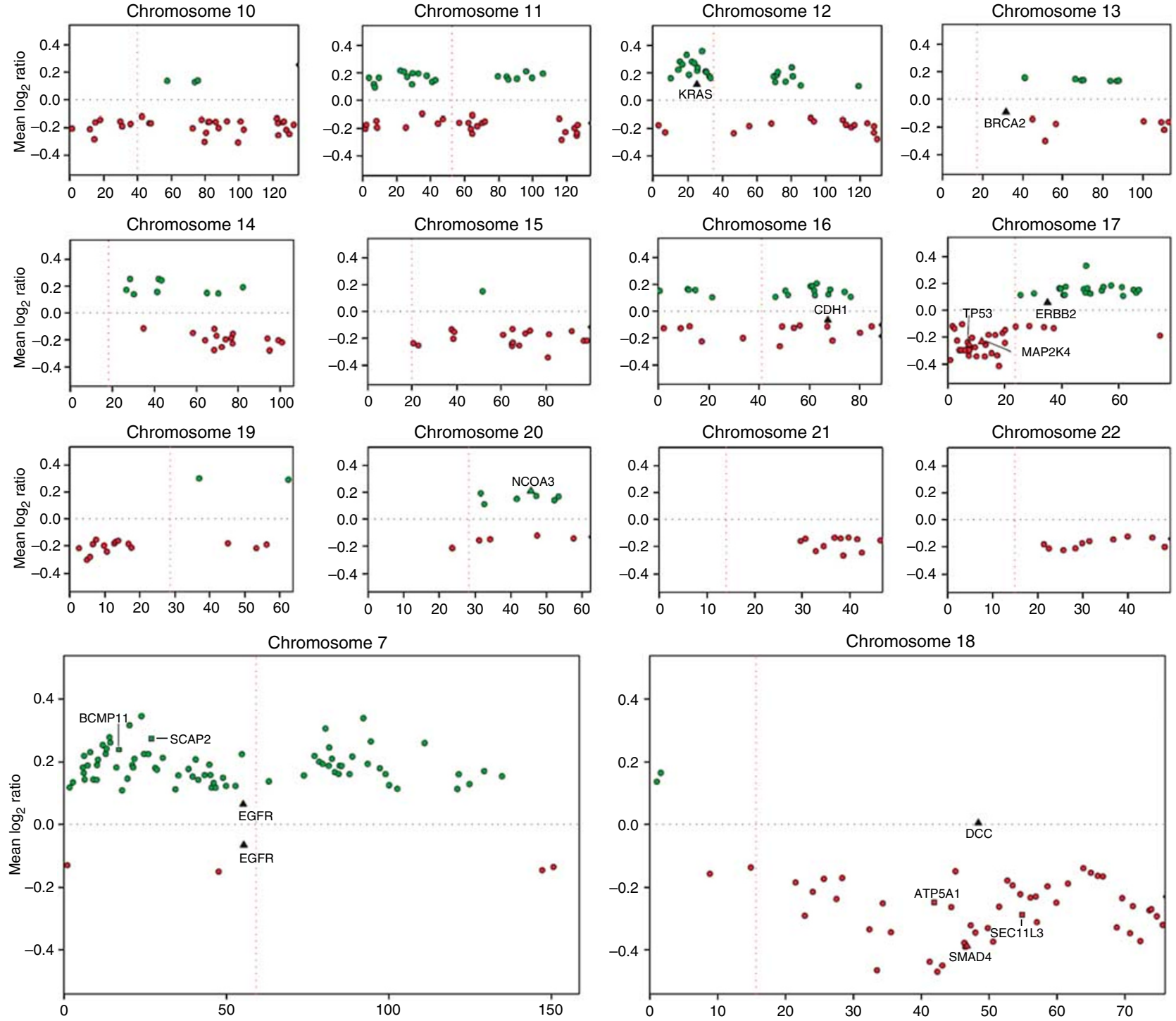

Figure I Summary of overall genome-wide alterations in a total of 23 microdissected PDAC tissues. Genetic gains are shown as green dots and losses as red dots ( $Y$ axis) at each clone position along the chromosome ( $X$ axis). Several representative clones with no genetic changes are depicted as black dots. Square-shaped dots indicate the clones validated by FISH, whereas triangle dots indicate previously identified genes in PDAC. Vertical dotted lines represent chromosome centromeres.

compared to the previous reports in which PDAC-derived cell lines were analysed (Aguirre et al, 2004; Bashyam et al, 2005; Gysin et al, 2005; Nowak et al, 2005). Although they displayed similar spectrum patterns of genetic alterations overall, we found that there were apparently different breakpoints in our profiles. Our data showed several segmented gains on chromosome 2, which 
have rarely been observed in cell lines. In contrast, losses of $4 \mathrm{q}$ and $13 q$ and gains of $11 q$ and $20 q$ in cell lines were not as frequent as in our microdissected samples. Next, we focused on individual clones harbouring the genes that are known to be dysregulated in cell lines. Increased copy numbers were detected in the regions including MYC (8q24.21) and NCOA3/AIB1 (20q13.12), while genetic losses were observed in the regions containing SMAD4 (18q21.1), TP53 (17p13.1), MAP2K4 (17p11.2) and RUNX3 (1p36.11). However, using the rigorous statistical conditions employed, we identified neither genetic gains of KRAS (12p12.1), $M Y B$ (6q23.3), EGFR (7p11.2) and ERBB2 (17q12) nor losses of MLH1 (3p22.2), BRCA2 (13q13.1) and CDH1 (16q22.1). (All the genes cited here are depicted in Figure 1.)

\section{Contiguous regions of nonrandom copy number changes}

In addition to numerous localised alterations, we detected a total of 41 contiguous regions $(>3.0 \mathrm{Mb})$ of nonrandom genomic changes (Table 2). For instance, increased copy number was detected in the $26.0 \mathrm{Mb}$ region of $7 \mathrm{p} 22.2-\mathrm{p} 15.1$ that contains 48 known or hypothetical protein-coding genes. We also defined the regions of genetic gains on $1 \mathrm{q}, 3 \mathrm{q}, 5 \mathrm{p}, 5 \mathrm{q}, 8 \mathrm{q}$ and $12 \mathrm{p}$, which may represent loci for candidate oncogenes in PDAC. The largest region of copy number loss was from $17 \mathrm{p} 13.3$ to $17 \mathrm{p} 12$ (13.6 Mb), which covers a total of 53 candidate genes including TP53 (17p13.1) as well as MAP2K4 (17p11.2). We delineated three contiguous regions of genomic loss on 18q, which is known to be a site of frequent deletions in PDAC, $18 \mathrm{q} 21.2-\mathrm{q} 22.1 \quad(12.0 \mathrm{Mb}), \quad 18 \mathrm{q} 22.3-\mathrm{q} 23$ $(7.1 \mathrm{Mb})$ and $18 \mathrm{q} 12.3-\mathrm{q} 21.2(6.9 \mathrm{Mb})$. The region of $18 \mathrm{q} 21.2-$ q22.1 harbours 16 candidate genes in addition to SMAD4 (18q21.1) that is one of the most recurrently inactivated tumour suppressor genes in PDAC. The region of 18q12.3- q21.2 contains a total of 23 putative target genes, whereas seven genes are included in the $7.1 \mathrm{Mb}$ region of $18 \mathrm{q} 22.3-\mathrm{q} 23$. Interestingly, the clone encompassing DCC (18q21.2) has shown an apparent discontinuity between two broad regions of genetic loss (18q12.3-q21.2 and 18q21.2-q22.1) in our 23 microdissected PDAC sample set (Figure 1).

\section{Verification of genetic changes by two-colour FISH}

To investigate prospectively whether the identified genetic abnormalities are prevalent in PDAC, interphase FISH analysis was performed using an independent sample set (Figure 2). Previous cytogenetic studies have shown that chromosome arms $7 \mathrm{p}$ and 18q may include oncogenes and tumour suppressor genes that play a critical role in pancreatic carcinogenesis (Griffin et al, 1995; Hahn et al, 1995; Fukushige et al, 1997, 1998; Mahlamaki et al, 1997; Schleger et al, 2000; Harada et al, 2002a; IacobuzioDonahue et al, 2004). Therefore, we prioritised three regions (7p22.3-p15.1, 18q12.3-q21.2 and 18q21.2-q22.1) of nonrandom copy number changes detected in array CGH and a subset of four BAC clones (RP11-403N12 at 7p21.1, RP11-232C20 at 7p15.2, $\mathrm{RP} 11-8 \mathrm{H} 2$ at $18 \mathrm{q} 21.1$ and RP11-350K6 at 18q21.32) were selected from those regions (Table 3). As shown in Table 4, deletion in the locus encompassing SEC11L3 (18q21.32) was observed to be the most recurrent alteration (13 out of 19 samples; 68\%) (Figure 2B). The region $18 \mathrm{q} 21.1$ defined by RP11-8H2 was deleted in 11 out of 19 cases (58\%) and contains three known candidate genes: ATP5A1, PSTPIP2 and CCDC5. RP11-403N12 including BCMP11 (7p21.1) showed an increased copy number in 10 out of 19 cases (53\%) (Figure 2C), whereas gain of the region at RP11-232C20 containing SCAP2 (7p15.2) was demonstrated in seven out of 19 cases $(37 \%)$ (Figure 2D).

\section{SEC11L3 mRNA downregulation detected by ISH and RT - PCR}

Subsequently, the SEC11L3 mRNA level was evaluated by ISH (Figure 3). Firstly, we tested several different types of normal epithelial cells from the pancreas, intestine and liver. Normal pancreatic tissues showed strong mRNA expression of SEC11L3 in both ductal and acinar cells (score 2), whereas there was weak expression in islet cells (score 1). Strong expression was also observed in normal intestinal and hepatic cells (score 2). Of 19 PDAC cases, SEC11L3 mRNA was downregulated (score $0-1$ ) in 11 cases $(58 \%)$, whereas it was unchanged (score 2) in eight cases

Table 2 Contiguous regions ( $>3.0 \mathrm{Mb}$ ) of chromosomal changes in a total of 23 microdissected PDAC tissues

\begin{tabular}{|c|c|c|c|c|c|c|c|c|c|}
\hline Locus & Start (bp) & End (bp) & Size $(\mathbf{M b})$ & Mean log2 & Locus & Start (bp) & End (bp) & Size (Mb) & Mean $\log 2$ \\
\hline | q24. | -q25. | & | 63809021 & 173127283 & 9.3 & 0.235 & Ip35. |-p34.3 & 34152076 & 38379441 & 4.2 & -0.232 \\
\hline l q25.2-q25.3 & 177942453 & 181046133 & 3.0 & 0.208 & $4 p|6.2-p| 6.1$ & 5094062 & 8313477 & 3.2 & -0.216 \\
\hline $\mid q 31.1-q 31.3$ & 187406225 & 195710013 & 8.3 & 0.255 & $6 p 21.32-p 21.31$ & 32031967 & 34013145 & 4.0 & -0.219 \\
\hline$|q 4|$ & 215371867 & 219919554 & 4.5 & 0.242 & $6 q 21$ & 108154127 & | I2486834 & 4.3 & -0.181 \\
\hline $\mathrm{q} 42.2-\mathrm{q} 43$ & 231700764 & 241495322 & 9.8 & 0.253 & $6 q 25.2-q 25.3$ & I 55289734 & I 58440778 & 3.2 & -0.204 \\
\hline $2 p|6.1-p| 4$ & $60927 \mid 85$ & 64676357 & 4.8 & 0.171 & $8 p 22-p 21.3$ & $17784 \mid 84$ & 21872595 & 4.1 & -0.264 \\
\hline $2 q 22.2-q 22.3$ & 143499638 & | $4677597 \mid$ & 3.3 & 0.168 & $9 p 24.3-p 24.1$ & 190 & 6659690 & 6.7 & -0.228 \\
\hline $2 q 32.1$ & | 85 | $4006 \mid$ & | $88357 \mid 86$ & 3.2 & 0.161 & $9 p 22.1-p 21.3$ & 19310506 & 23557472 & 4.2 & -0.256 \\
\hline $2 q 32.3$ & 192914919 & 196752218 & 3.8 & 0.146 & $9 q 22.31-q 22.33$ & 94281893 & 100889311 & 6.6 & -0.171 \\
\hline $3 q 26.1$ & 163532324 & $16750 \mid 265$ & 4.0 & 0.237 & $9 q 33.3-q 34.11$ & $12612792 \mid$ & 129390787 & 3.3 & -0.216 \\
\hline $5 p|5.3|-p \mid 5.2$ & 7449057 & 10495937 & 3.0 & 0.165 & $9 q 34.13-q 34.3$ & 133982008 & 137333442 & 3.4 & -0.226 \\
\hline $5 p|4.3-p| 4.1$ & 20429524 & 28918008 & 8.5 & 0.232 & $|7 p| 3.3-p \mid 2$ & 800495 & 14360892 & 13.6 & -0.252 \\
\hline $5 q|1.1-q| 1.2$ & $5006 \mid 482$ & 54725678 & 4.7 & 0.174 & $|8 q| 2.3-q 2 \mid .2$ & 41216566 & 48119508 & 6.9 & -0.350 \\
\hline $5 q|2.2-q| 3.1$ & 63325516 & 66888015 & 3.6 & 0.149 & $18 q 21.2-q 22.1$ & 49795841 & 61752947 & 12.0 & -0.252 \\
\hline $5 q|4|-q \mid 4.3$. & 80075105 & 86472400 & 6.4 & 0.168 & $18 q 22.3-q 23$ & 68809458 & 75940259 & 7.1 & -0.294 \\
\hline $5 q \mid 4.3$ & 87676680 & 90964362 & 3.3 & 0.170 & $21 \mathrm{q} 21.3-\mathrm{q} 22.11$ & 29627040 & 34602938 & 5.0 & -0.182 \\
\hline $7 p 22.2-p 15.1$ & 2607390 & 28603446 & 26.0 & 0.207 & $22 q \mid 1.22-q 12.1$ & 21400636 & 25896652 & 4.5 & -0.205 \\
\hline $7 p \mid 4.1$ & 38185228 & 41345287 & 3.2 & 0.170 & $22 q|2.2-q| 2.3$ & 28379384 & 31627100 & 3.2 & -0.180 \\
\hline $7 q 21.11$ & $79539|3|$ & 83414012 & 3.9 & 0.219 & & & & & \\
\hline $8 q 21.11-q 21.13$ & 77234275 & 81648851 & 4.4 & 0.225 & & & & & \\
\hline $8 q 21.13-q 21.3$ & 82640038 & 89400934 & 6.8 & 0.271 & & & & & \\
\hline $8 q 24.11-q 24.13$ & | | 8297084 & 123697997 & 5.4 & 0.254 & & & & & \\
\hline$|2 p| 2.3-p \mid 2.1$ & 19403674 & 23784534 & 4.4 & 0.268 & & & & & \\
\hline
\end{tabular}

$\mathrm{PDAC}=$ pancreatic ductal adenocarcinoma. 
Table 3 Contiguous regions of nonrandom copy number changes on $7 p$ and $18 q$

\begin{tabular}{|c|c|c|c|c|c|c|c|c|c|c|}
\hline \multicolumn{5}{|c|}{ BAC } & $\frac{\text { Region }}{\text { Size }(M b)^{c}}$ & \multicolumn{2}{|r|}{ Genes included $^{\mathbf{a}}$} & \multicolumn{3}{|c|}{ Overall results } \\
\hline RPII-172013 & $7 p 22.1$ & 5704716 & 5847079 & 142364 & & 1 & TRIAD3 & 0.182 & 1.135 & $5.25 \mathrm{E}-06$ \\
\hline RPI-42M2 & $7 \mathrm{p} 22.1$ & 5969700 & 6049710 & 80011 & & 7 & PMS2, EIF2AKI & 0.165 & 1.121 & 0.000272 \\
\hline RP4-8I OE6 & $7 p 22.1$ & 6049510 & 6202437 & 152928 & & 6 & PSCD3, EIF2AKI & 0.220 & 1.164 & $1.23 \mathrm{E}-06$ \\
\hline RPII-425P5 & $7 \mathrm{p} 22.1$ & 6233987 & 6446613 & 212627 & & 4 & RACI, PSCD3 & 0.144 & 1.105 & 0.000254 \\
\hline RPII-304AIO & $7 p 21.3$ & 8950512 & 9040173 & 89662 & & 0 & & 0.144 & 1.105 & 0.000274 \\
\hline RP5-959C2I & $7 p 21.3$ & 9924891 & 10064840 & 139950 & & 0 & & 0.143 & 1.104 & $6.08 \mathrm{E}-06$ \\
\hline RPII-352E 12 & $7 \mathrm{p} 21.3$ & 10064640 & 10151963 & 87324 & & 0 & & 0.190 & 1.141 & $2.08 \mathrm{E}-06$ \\
\hline RPII-392PI & $7 p 21.3$ & 10372373 & 10429780 & 57408 & & 0 & & 0.207 & 1.155 & $3.66 \mathrm{E}-08$ \\
\hline RPII-502P9 & $7 \mathrm{p} 21.3$ & 11782368 & 1/ 938707 & 156340 & & 0 & & 0.254 & 1.192 & $5.32 \mathrm{E}-09$ \\
\hline RP5-I I00A7 & $7 p 21.3$ & 12725574 & |282738| & 101808 & & 0 & & 0.226 & 1.170 & $9.02 \mathrm{E}-09$ \\
\hline RPII-195LI4 & $7 p 21.3$ & 12951352 & 13077542 & 126191 & & 0 & & 0.242 & 1.183 & 1.45E-08 \\
\hline RPII-7|FI8 & $7 \mathrm{p} 21.1-\mathrm{p} 15.3$ & 19406242 & 19580569 & 174328 & & 0 & & 0.147 & 1.107 & $8.00 \mathrm{E}-06$ \\
\hline RPII-486PII & $7 p 15.3$ & 20042179 & 20150597 & 108419 & & 1 & $7 A 5$ & 0.317 & 1.246 & |.30E-11 \\
\hline RP4-701O19 & $7 p 15.3$ & 20884182 & 20950414 & 66233 & & 0 & & 0.190 & 1.140 & 4.72E-05 \\
\hline RPII-2IIJI5 & $7 p 15.3$ & 21173901 & 21257598 & 83698 & & 2 & & 0.183 & 1.135 & $2.43 \mathrm{E}-07$ \\
\hline RPII-445OI & $7 p 15.3$ & 21588234 & 21669042 & 80809 & & 1 & DNAHII & 0.210 & 1.157 & 9.97E-08 \\
\hline RPII-45IFII & $7 p 15.3$ & 23714553 & 23804532 & 89980 & & 1 & STK3I & 0.346 & 1.271 & $1.43 \mathrm{E}-1 \mid$ \\
\hline RPII-343P2I & $7 p 15.3$ & 24511504 & 24521807 & 10304 & & 0 & & 0.226 & 1.169 & 3.17E-08 \\
\hline RPII-99017 & $7 p 15.2$ & 25824267 & 25925677 & $10|4| 1$ & & 0 & & 0.225 & 1.169 & 2.79E-07 \\
\hline RPII-232C20 & $7 p / 5.2$ & 26765660 & 26911371 & $|457| 2$ & & I & SCAP2 & 0.275 & 1.210 & I.80E-10 \\
\hline RP4-78|A|8 & 7pl5.2-p|5.1 & $27976|7|$ & 28166812 & 190642 & & 2 & tcag7.981 & 0.181 & 1.133 & $1.83 \mathrm{E}-06$ \\
\hline RP4-59609 & $7 p \mid 5.1$ & 28459769 & 28603446 & 143678 & & 1 & CREB5 & 0.175 & 1.129 & $8.62 \mathrm{E}-06$ \\
\hline RPII-463DI7 & $18 \mathrm{q} \mid 2.3$ & 41216566 & 41408713 & $192 \mid 48$ & 6.9 & 0 & & -0.439 & -1.356 & $1.00 \mathrm{E}-11$ \\
\hline RPII-8H2 & | 8q2I.| & $4|85| 567$ & 41984947 & $|3338|$ & & 5 & ATP5AI, CCDC5, PSTPIP2 & -0.249 & -1.189 & I.50E-07 \\
\hline RPII-116K4 & $18 q 21.2$ & 49795841 & $4997 \mid 830$ & 175990 & 12.0 & । & MBD2 & -0.331 & -1.258 & 6.44E-08 \\
\hline RPII-99A| & $18 q 21.2$ & $50563|5|$ & 50702093 & 138943 & & i & $R A B 27 B$ & -0.374 & -1.296 & 4.86E-08 \\
\hline RPII-397A 16 & $18 \mathrm{q} 21.2$ & 51445553 & 51648118 & 202566 & & 1 & & -0.263 & -1.200 & $1.58 \mathrm{E}-07$ \\
\hline RPII-383D22 & $18 q 21.31$ & 52656265 & 52867730 & 211466 & & 2 & WDR7 & -0.179 & -1.132 & 0.000196 \\
\hline RPII-35G9 & $|8 q 21.3|$ & 53447744 & 53561700 & 113957 & & 4 & ATP8B I & -0.195 & -1.145 & $1.99 \mathrm{E}-06$ \\
\hline$R P||-6|J| 4$ & $18 q 21.32$ & 54567090 & 54747580 & $|8049|$ & & 6 & ZNF532, MALTI & -0.223 & -1.167 & 3.87E-07 \\
\hline RPII-350K6 & $18 q 21.32$ & 54867252 & 55027999 & 160748 & & $\mathbf{I}$ & SECIIL3 & -0.289 & -1.222 & 5.58E-09 \\
\hline RPII-396NII & $18 q 21.32$ & 56063594 & $56|5| 592$ & 87999 & & 0 & & -0.233 & -1.176 & 7.74E-08 \\
\hline RPII-520K।8 & $18 q 21.32$ & 56874822 & $57034 w 619$ & 159798 & & 0 & & -0.230 & -1.173 & $1.22 \mathrm{E}-06$ \\
\hline RPII-I3L22 & $18 q 21.33$ & 58408978 & 58578530 & 169553 & & 3 & $P H L P P$ & -0.320 & -1.248 & $3.63 \mathrm{E}-11$ \\
\hline$R P \mid I-215 A 20$ & $18 q 21.33$ & 58572412 & 58756503 & 184092 & & 2 & PHLPP & -0.198 & -1.147 & $1.24 \mathrm{E}-05$ \\
\hline RPII-233010 & $18 q 22.1$ & 59886252 & 59971318 & 85067 & & 1 & Cl8orf20 & -0.250 & -1.189 & $2.21 \mathrm{E}-10$ \\
\hline RPII-389J22 & 18q22.1 & 61594898 & 61752947 & 158050 & & 1 & $\mathrm{CDH7}$ & -0.189 & -1.140 & 8.76E-07 \\
\hline RPII-169FI7 & $18 q 22.3$ & 68809458 & 69000813 & 191356 & 7.1 & 0 & & -0.329 & -1.256 & $4.02 \mathrm{E}-10$ \\
\hline RPII-25L3 & $18 q 22.3$ & 69588036 & 69755177 & $167 \mid 42$ & & 0 & & -0.236 & -1.177 & 8.63E-08 \\
\hline RPII-556LI5 & 18q22.3 & 70753437 & 70931323 & 177887 & & 1 & ZNF407 & -0.348 & -1.272 & 3.55E-09 \\
\hline RPII-396D4 & $18 q 22.3-q 23$ & 71168342 & 71337306 & 168965 & & 1 & & -0.261 & -1.198 & 1.5IE-07 \\
\hline RPII-234NI & $18 q 23$ & 72266630 & 72448 । I 8 & 181489 & & 2 & ZNF5I6 & -0.373 & -1.295 & $3.4|\mathrm{E}-1|$ \\
\hline RPII-1|812 & $18 \mathrm{q} 23$ & 73613846 & 73764173 & 150328 & & 0 & & -0.275 & -1.210 & $1.20 \mathrm{E}-06$ \\
\hline RPII-16L7 & $18 q 23$ & 73908671 & 74017409 & 108739 & & 0 & & $-0.27 \mid$ & -1.206 & $2.94 \mathrm{E}-12$ \\
\hline RPI|-563B|I & $18 \mathrm{q} 23$ & 74707626 & 74870951 & 163326 & & । & SALL3 & -0.294 & -1.226 & $3.81 \mathrm{E}-07$ \\
\hline RPII-I54HI2 & $18 q 23$ & 75586355 & $7570 \mid 258$ & 114904 & & 2 & CTDPI & -0.321 & -1.249 & $1.20 \mathrm{E}-08$ \\
\hline CTC-964M9 & $18 \mathrm{q} 23$ & 75939424 & 75940259 & 836 & & 0 & & -0.230 & -1.173 & $9.86 \mathrm{E}-06$ \\
\hline
\end{tabular}

${ }^{a}$ The four clones that were used in FISH analysis are outlined in bold. ${ }^{\mathrm{b}}$ The size of the contiguous region. ${ }^{\mathrm{c}}$ The number of genes included in each clone and examples of candidate genes contained within each clone. All the details are shown in Supplementary Table I. 
Table 4 The results of FISH and ISH analyses ${ }^{a}$

\begin{tabular}{|c|c|c|c|c|c|}
\hline $\begin{array}{l}\text { Clone ID/candidate } \\
\text { Analysis }\end{array}$ & $\begin{array}{c}\text { RPII-403N I } 2 / B C M P I I \\
\text { FISH }\end{array}$ & $\begin{array}{c}\text { RPII-232C20/SCAP2 } \\
\text { FISH }\end{array}$ & $\begin{array}{c}\text { RPII-8H2/ATP5A I } \\
\text { FISH }\end{array}$ & \multicolumn{2}{|c|}{ RPII-350K6/SECIIL3 } \\
\hline PC38 & 1.02 & 1.12 & 0.94 & 0.94 & 2 \\
\hline PC39 & 0.98 & 1.09 & 1.05 & 0.77 & 0 \\
\hline PC40 & 1.01 & 1.30 & 0.95 & 0.57 & I \\
\hline PC4I & 1.13 & 0.93 & 0.20 & 0.46 & 0 \\
\hline PC44 & 1.35 & 1.52 & 0.66 & 0.94 & 2 \\
\hline PC45 & 1.01 & 1.01 & 0.63 & 0.71 & I \\
\hline PC46 & 1.06 & 1.13 & 0.94 & 0.86 & 2 \\
\hline PC47 & 0.98 & 1.03 & 0.74 & 0.36 & 0 \\
\hline PC48 & 1.59 & 0.94 & 0.90 & 0.51 & 0 \\
\hline PC49 & 1.17 & 1.24 & 0.58 & 1.04 & 2 \\
\hline PC50 & 1.01 & 1.03 & 0.94 & 0.63 & 0 \\
\hline Frequency (\%) & $10 / 19(53 \%)$ & $7 / 19(37 \%)$ & $11 / 19(58 \%)$ & $13 / 19(68 \%)$ & $11 / 19(58 \%)$ \\
\hline
\end{tabular}

${ }^{a}$ Significant differences are outlined in bold. FISH = fluorescence in situ hybridisation; ISH = in situ RNA hybridisation.
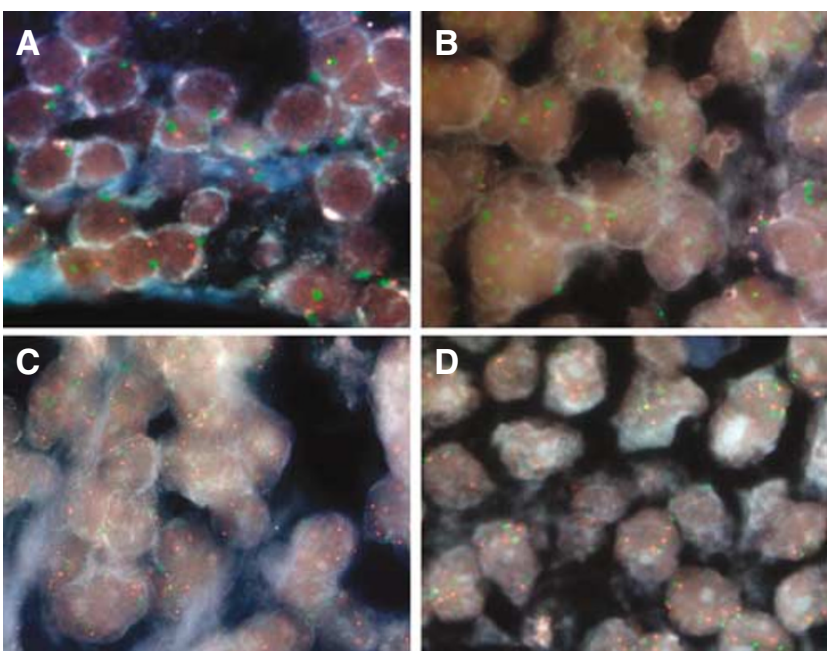

Figure 2 Four representative images in FISH analysis. Target BAC DNA probes were labelled with Cy3-dCTP (red), while centromeric probes were labelled with SpectrumGreen. DNA copy number was evaluated for each probe by counting spots in at least 100 nuclei. (A) No copy number change of BCMPII in PC40. (B) Genetic loss of SECI IL3 in PC48. (C) Genetic gains of BCMP II in PC44 and (D) of SCAP2 in PC49.

(42\%) (Table 4). All 11 cases with downregulated SEC11L3 demonstrated genetic losses by FISH. Despite decreased copy numbers, SEC11L3 was expressed in two samples (PC46 and PC51). A significant correlation between deletion and expression levels was found ( $P=0.001$, Fisher's exact test), indicating that the mRNA level of this gene was highly dependent on its DNA copy number.

RT-PCR was performed further to confirm downregulated mRNA of SEC11L3 in PDAC. Figure 4 shows SEC11L3 expression in normal pancreas and PDAC tissue samples. Compared to two normal pancreas tissues, SEC11L3 was found to be downregulated in 16 out of 16 PDAC samples (100\%). In particular, the SEC11L3 transcript was virtually almost absent in four PDAC tissues (25\%; lane 5, 6, 7 and 15).

\section{DISCUSSION}

It is well known that a strong desmoplastic reaction is a typical feature of PDAC tissues. A dense stromal component, which occupies larger parts of the tumour mass, significantly reduces the sensitivity and specificity of cytogenetic analysis. Tissue microdissection is laborious, but the practical method available to enrich the tumour cell population in clinical specimens. In the present study, we first identified genomic abnormalities that represent the characteristics of tumour cells in vivo by combining CGH arrays with tissue microdissection. This approach led to more precise definition of chromosomal breakpoints in a panel of 23 PDAC tissue samples. To identify nonrandom genomic changes in PDAC, we applied a $P$-value rather than a fixed cutoff value because we found that concomitant lack of power in dichotomising the data at an early stage in the analysis provided poor resolution with which to distinguish between clones. Taking a statistical threshold approach allows us to take account of different clones' differing variance across samples that a fixed fold-change approach does not.

We compared the CGH profiles to the previously published cell line data (Karhu et al, 2006). Despite overall similar spectrum patterns, there were clear differences between both profiles. It is important to take into account that the resolution of CGH arrays used and the type of statistical analysis employed vary widely between the reports. However, our results indicated that some recurrent genetic alterations, such as losses of $4 q$ and $13 q$ and gains of $11 \mathrm{q}$ and $20 \mathrm{q}$, seem to be relatively unique to cell lines, implying that these genetic changes may have been artificially acquired through the establishment of cell lines or in the course of culturing. In addition, our data did not demonstrate significant copy number changes of some known genes, such as KRAS, $E R B B 2, M L H 1$ and $C D H 1$. This is probably due to the fact that intragenic mutation or promoter methylation is more likely to occur in these genes (Lemoine et al, 1992; Scarpa et al, 1994; Rozenblum et al, 1997; Ueki et al, 2000). Alternatively, this discrepancy could be explained by the intratumoral heterogeneity that is characteristically observed in PDAC cells in vitro as well as in vivo, or may reflect the differences of the geographic origin of the tumours used in this study (a total of 42 Japanese samples were 

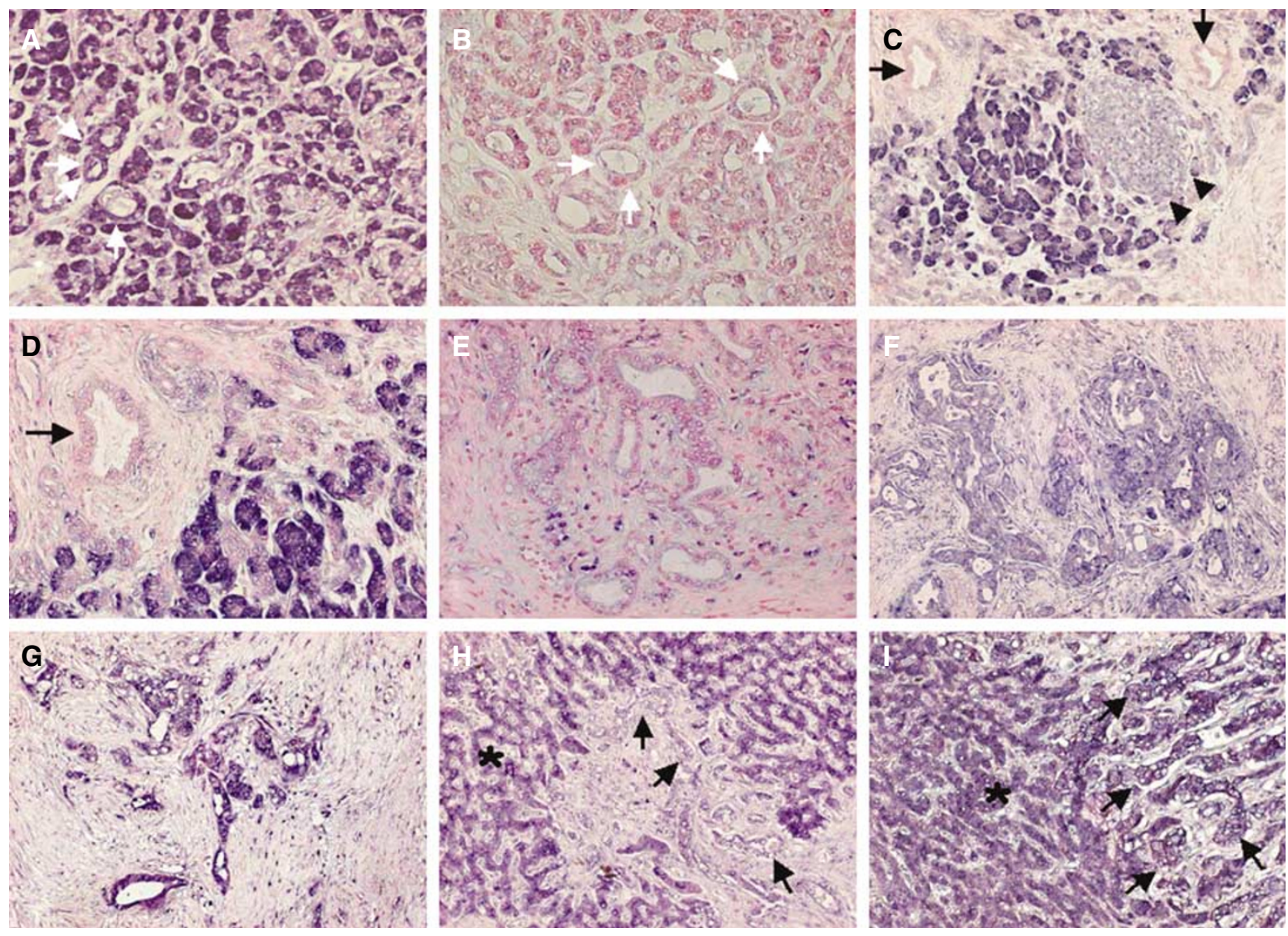

Figure 3 SECI IL3 mRNA expression in non-neoplastic epithelial cells and PDAC cells, as determined by ISH. (A) Strong expression (score 2) in both ductal (white arrows) and acinar cells of non-neoplastic pancreas. (B) ISH conducted with a sense SECI IL3 riboprobe, used as a negative control. (C $-\mathbf{E}$ ). No expression (score 0) in PDAC cells (black arrows), but weak expression (score I) in non-neoplastic islet cells (black arrow heads) (PC4I and 47) (F). Weak expression (score I) of PDAC cells in PC43 and (G) strong intensity of expression (score 2) of PDAC cells in PC44. (H) Lower level of expression (score I; PC53) and (I) similar intensity of expression (score 2; PC55) in metastatic PDAC cells (black arrows) compared to non-neoplastic hepatic cells (asterisk).

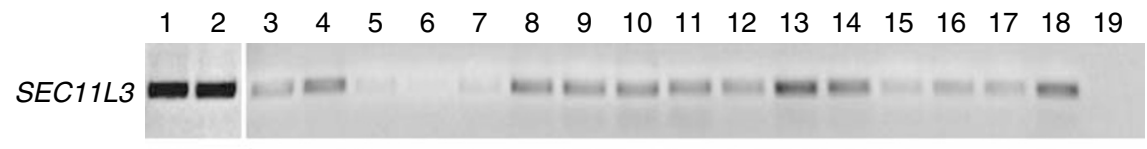

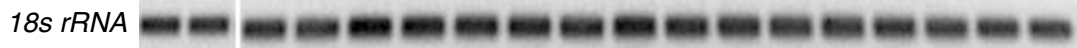

Figure 4 mRNA expression of SECI IL3 in normal pancreas and PDAC tissues, as determined by RT-PCR. I8S ribosomal RNA was used as an internal standard. Samples were run in the following order: lane I-2, normal pancreas; lane 3- I8, PDACs; lane 19, negative control. SECI IL3 expression was found to be present in normal pancreas, while it was decreased in 16 out of 16 PDAC tissues (100\%).

analysed by array CGH, FISH and ISH) (Scarpa et al, 1994; Gorunova et al, 1998; Harada et al, 2002b). Similarly, deletion of the DCC gene was not recurrent in our sample set. However, a larger scale of study using much higher-resolution genomewide microarrays (tiling-path $\mathrm{CGH}$ arrays or single nucleotide polymorphism arrays) is required to conclude whether this genetic alteration is critically involved in the pathogenesis of PDAC.

As our array CGH profiles revealed that the regions of $7 \mathrm{p} 22.2-$ $\mathrm{p} 15.1,18 \mathrm{q} 12.3-\mathrm{q} 21.2$ and $18 \mathrm{q} 21.2-\mathrm{q} 22.1$ are nonrandomly altered, four clones from those regions were validated by FISH experiments. The results showed that genetic alterations for these clones were observed in $37-68 \%$ of tumours in a separate sample set, supporting the validity of our CGH results. Moreover, copy number changes of those four clones were detected in 18 out of 19
PDAC cases (95\%), implying the potential clinical applicability. Among the candidate genes verified by FISH, BCMP11 is newly detected in PDAC, although Fletcher et al (2003) demonstrated that mRNA and protein of this gene were overexpressed in oestrogen receptor-positive breast cancer. This gene lies adjacent to the AGR2 gene (7p21.1) and both genes are classified as members of the same family (AGR family) due to highly similar (approximately 70\%) protein sequences. Interestingly, several gene expression analyses have shown that AGR2 is upregulated in the majority of PDACs as well as pancreatic intraepithelial neoplasia (PanIN) lesions (Crnogorac-Jurcevic et al, 2003; IacobuzioDonahue et al, 2003a; Iacobuzio-Donahue et al, 2003b; Missiaglia et al, 2004; Buchholz et al, 2005). Taken together, BCMP11 is also likely to be involved in the development of PDAC. On the other hand, SCAP2 was first described in a recently published report, 
showing that mRNA of this gene is frequently overexpressed in PanIN lesions (Buchholz et al, 2005). The protein encoded by this gene belongs to the src family of kinases. Takahashi et al (2003) demonstrated that SCAP2 functions as a downstream target of c-Src under various stress conditions (UV light, tumour necrosis factor- $\alpha$ and osmotic stress). Therefore, SCAP2 also seems to work as a cell-signalling molecule in cancer cells. However, the biological function and putative role of these two genes have not been investigated in cancer.

Remarkably, SEC11L3 was deleted in approximately $70 \%$ of tumours and its expression level was significantly correlated with its DNA copy number. Despite the high frequency of this genetic abnormality, this gene has not been described in any type of cancer. Previous cytogenetic analyses have revealed a frequent deletion of $18 \mathrm{q}$ in PDAC, but neither the chromosomal breakpoints nor the candidate genes included could be clearly identified due to technical limitations of the technology employed (Griffin et al, 1995; Hahn et al, 1995; Fukushige et al, 1997, 1998; Mahlamaki et al, 1997; Hoglund et al, 1998; Schleger et al, 2000; Harada et al, 2002a; Iacobuzio-Donahue et al, 2004). SMAD4 (18q21.1) has been reported to be deleted or inactivated in about $50 \%$ of PDACs and, therefore, it is considered to be one of the most likely candidate tumour suppressor genes at this locus (Hahn et al, 1996; Rozenblum et al, 1997). However, we propose that SEC11L3 (18q21.32) could be an equally promising candidate gene on $18 \mathrm{q}$ because the significance of genetic loss of this gene is comparable to that of the SMAD4 gene. In addition, both ISH and RT-PCR independently confirmed that SEC11L3 mRNA is downregulated in PDAC tissues at a high frequency $(53 \%$ and $100 \%$, respectively), suggesting that dysregulation of this gene is likely to be associated with the development of PDAC. Little is known about the biological role of this gene, although it belongs to the peptidase S26B family and functions as part of the signal peptidase complex.

In summary, we could successfully identify genetic alterations that reflect the intrinsic characteristics of PDAC cells in vivo by combining array CGH with tissue microdissection. These results provided a valid data set to search for novel candidate genes involved in pancreatic carcinogenesis. The specificity of our array CGH results was confirmed by interphase FISH in an independent sample set. Among the identified candidates, we are particularly interested in the SEC11L3 gene that is located on 18q21.32. FISH and ISH analyses for this gene demonstrated a significant correlation between genetic deletion and the corresponding mRNA downregulation, raising the possibility that the SEC11L3 gene may play a putative role as a tumour suppressor. For these reasons, we propose that SEC11L3 should be considered as a potential marker gene for the molecular diagnosis of PDAC and a possible candidate target for therapeutic intervention.

\section{ACKNOWLEDGEMENTS}

This study was supported by Cancer Research UK (C355/A6253). We thank Professor Nigel P Carter (The Wellcome Trust Sanger Institute) for providing $1 \mathrm{Mb}$ CGH arrays. In addition, we thank Professor Kiwamu Okita (Department of Gastroenterology and Hepatology, Yamaguchi University School of Medicine) and Dr Makoto Sunamura (Department of Surgery, Tohoku University School of Medicine) for providing clinical samples of PDAC.

Supplementary Information accompanies the paper on British Journal of Cancer website (http://www.nature.com/bjc)

\section{REFERENCES}

Aguirre AJ, Brennan C, Bailey G, Sinha R, Feng B, Leo C, Zhang Y, Zhang J, Gans JD, Bardeesy N, Cauwels C, Cordon-Cardo C, Redston MS, DePinho RA, Chin L (2004) High-resolution characterization of the pancreatic adenocarcinoma genome. Proc Natl Acad Sci USA 101: 9067-9072

Albertson DG, Ylstra B, Segraves R, Collins C, Dairkee SH, Kowbel D, Kuo WL, Gray JW, Pinkel D (2000) Quantitative mapping of amplicon structure by array CGH identifies CYP24 as a candidate oncogene. Nat Genet 25: $144-146$

Bashyam MD, Bair R, Kim YH, Wang P, Hernandez-Boussard T, Karikari CA, Tibshirani R, Maitra A, Pollack JR (2005) Array-based comparative genomic hybridization identifies localized DNA amplifications and homozygous deletions in pancreatic cancer. Neoplasia 7: 556-562

Buchholz M, Braun M, Heidenblut A, Kestler HA, Kloppel G, Schmiegel W, Hahn SA, Luttges J, Gress TM (2005) Transcriptome analysis of microdissected pancreatic intraepithelial neoplastic lesions. Oncogene 24: $6626-6636$

Crnogorac-Jurcevic T, Missiaglia E, Blaveri E, Gangeswaran R, Jones M, Terris B, Costello E, Neoptolemos JP, Lemoine NR (2003) Molecular alterations in pancreatic carcinoma: expression profiling shows that dysregulated expression of S100 genes is highly prevalent. J Pathol 201: $63-74$

Fiegler H, Carr P, Douglas EJ, Burford DC, Hunt S, Scott CE, Smith J, Vetrie D, Gorman P, Tomlinson IP, Carter NP (2003) DNA microarrays for comparative genomic hybridization based on DOP-PCR amplification of BAC and PAC clones. Genes Chromosomes Cancer 36: 361-374

Fletcher GC, Patel S, Tyson K, Adam PJ, Schenker M, Loader JA, Daviet L, Legrain P, Parekh R, Harris AL, Terrett JA (2003) hAG-2 and hAG-3, human homologues of genes involved in differentiation, are associated with oestrogen receptor-positive breast tumours and interact with metastasis gene C4.4a and dystroglycan. Br J Cancer 88: 579-585

Fukushige S, Furukawa T, Satoh K, Sunamura M, Kobari M, Koizumi M, Horii A (1998) Loss of chromosome $18 \mathrm{q}$ is an early event in pancreatic ductal tumorigenesis. Cancer Res 58: $4222-4226$
Fukushige S, Waldman FM, Kimura M, Abe T, Furukawa T, Sunamura M, Kobari M, Horii A (1997) Frequent gain of copy number on the long arm of chromosome 20 in human pancreatic adenocarcinoma. Genes Chromosomes Cancer 19: $161-169$

Gentleman RC, Carey VJ, Bates DM, Bolstad B, Dettling M, Dudoit S, Ellis B, Gautier L, Ge Y, Gentry J, Hornik K, Hothorn T, Huber W, Iacus S, Irizarry R, Leisch F, Li C, Maechler M, Rossini AJ, Sawitzki G, Smith C, Smyth G, Tierney L, Yang JY, Zhang J (2004) Bioconductor: open software development for computational biology and bioinformatics. Genome Biol 5: R80

Gorunova L, Hoglund M, Andren-Sandberg A, Dawiskiba S, Jin Y, Mitelman F, Johansson B (1998) Cytogenetic analysis of pancreatic carcinomas: intratumor heterogeneity and nonrandom pattern of chromosome aberrations. Genes Chromosomes Cancer 23: 81-99

Griffin CA, Hruban RH, Morsberger LA, Ellingham T, Long PP, Jaffee EM, Hauda KM, Bohlander SK, Yeo CJ (1995) Consistent chromosome abnormalities in adenocarcinoma of the pancreas. Cancer Res 55: $2394-2399$

Gysin S, Rickert P, Kastury K, McMahon M (2005) Analysis of genomic DNA alterations and mRNA expression patterns in a panel of human pancreatic cancer cell lines. Genes Chromosomes Cancer 44: 37-51

Hahn SA, Schutte M, Hoque AT, Moskaluk CA, da Costa LT, Rozenblum E, Weinstein CL, Fischer A, Yeo CJ, Hruban RH, Kern SE (1996) DPC4, a candidate tumor suppressor gene at human chromosome 18q21.1. Science 271: $350-353$

Hahn SA, Seymour AB, Hoque AT, Schutte M, da Costa LT, Redston MS, Caldas C, Weinstein CL, Fischer A, Yeo CJ, Hruban RH, Kern SE (1995) Allelotype of pancreatic adenocarcinoma using xenograft enrichment. Cancer Res 55: 4670-4675

Harada T, Okita K, Shiraishi K, Kusano N, Furuya T, Oga A, Kawauchi S, Kondoh S, Sasaki K (2002a) Detection of genetic alterations in pancreatic cancers by comparative genomic hybridization coupled with tissue microdissection and degenerate oligonucleotide primed polymerase chain reaction. Oncology 62: 251-258 
Harada T, Okita K, Shiraishi K, Kusano N, Kondoh S, Sasaki K (2002b) Interglandular cytogenetic heterogeneity detected by comparative genomic hybridization in pancreatic cancer. Cancer Res 62: $835-839$

Heidenblad M, Schoenmakers EF, Jonson T, Gorunova L, Veltman JA, van Kessel AG, Hoglund M (2004) Genome-wide array-based comparative genomic hybridization reveals multiple amplification targets and novel homozygous deletions in pancreatic carcinoma cell lines. Cancer Res 64: $3052-3059$

Hoglund M, Gorunova L, Jonson T, Dawiskiba S, Andren-Sandberg A, Stenman G, Johansson B (1998) Cytogenetic and FISH analyses of pancreatic carcinoma reveal breaks in $18 \mathrm{q} 11$ with consistent loss of 18q12-qter and frequent gain of 18p. Br J Cancer 77: 1893-1899

Holzmann K, Kohlhammer H, Schwaenen C, Wessendorf S, Kestler HA, Schwoerer A, Rau B, Radlwimmer B, Dohner H, Lichter P, Gress T, Bentz M (2004) Genomic DNA-chip hybridization reveals a higher incidence of genomic amplifications in pancreatic cancer than conventional comparative genomic hybridization and leads to the identification of novel candidate genes. Cancer Res 64: 4428-4433

Hurst CD, Fiegler H, Carr P, Williams S, Carter NP, Knowles MA (2004) High-resolution analysis of genomic copy number alterations in bladder cancer by microarray-based comparative genomic hybridization. Oncogene 23: $2250-2263$

Iacobuzio-Donahue CA, Ashfaq R, Maitra A, Adsay NV, Shen-Ong GL, Berg K, Hollingsworth MA, Cameron JL, Yeo CJ, Kern SE, Goggins M Hruban RH (2003a) Highly expressed genes in pancreatic ductal adenocarcinomas: a comprehensive characterization and comparison of the transcription profiles obtained from three major technologies. Cancer Res 63: 8614-8622

Iacobuzio-Donahue CA, Maitra A, Olsen M, Lowe AW, van Heek NT, Rosty C, Walter K, Sato N, Parker A, Ashfaq R, Jaffee E, Ryu B, Jones J, Eshleman JR, Yeo CJ, Cameron JL, Kern SE, Hruban RH, Brown PO, Goggins M (2003b) Exploration of global gene expression patterns in pancreatic adenocarcinoma using cDNA microarrays. Am J Pathol 162: $1151-1162$

Iacobuzio-Donahue CA, van der Heijden MS, Baumgartner MR, Troup WJ, Romm JM, Doheny K, Pugh E, Yeo CJ, Goggins MG, Hruban RH, Kern SE (2004) Large-scale allelotype of pancreaticobiliary carcinoma provides quantitative estimates of genome-wide allelic loss. Cancer Res 64: $871-875$

Jain AN, Tokuyasu TA, Snijders AM, Segraves R, Albertson DG, Pinkel D (2002) Fully automatic quantification of microarray image data. Genome Res 12: $325-332$

Jemal A, Murray T, Ward E, Samuels A, Tiwari RC, Ghafoor A, Feuer EJ, Thun MJ (2005) Cancer statistics, 2005. CA Cancer J Clin 55: 10-30

Karhu R, Mahlamaki E, Kallioniemi A (2006) Pancreatic adenocarcinoma genetic portrait from chromosomes to microarrays. Genes Chromosomes Cancer 45: 721 - 730

Lemoine NR, Jain S, Hughes CM, Staddon SL, Maillet B, Hall PA, Kloppel G (1992) Ki-ras oncogene activation in preinvasive pancreatic cancer. Gastroenterology 102: $230-236$

Lu YJ, Birdsall S, Summersgill B, Smedley D, Osin P, Fisher C, Shipley J (1999) Dual colour fluorescence in situ hybridization to paraffinembedded samples to deduce the presence of the $\operatorname{der}(\mathrm{X}) \mathrm{t}(\mathrm{X} ; 18)$ (p11.2;q11.2) and involvement of either the SSX1 or SSX2 gene: a diagnostic and prognostic aid for synovial sarcoma. J Pathol 187: 490-496

Mahlamaki EH, Hoglund M, Gorunova L, Karhu R, Dawiskiba S, AndrenSandberg A, Kallioniemi OP, Johansson B (1997) Comparative genomic hybridization reveals frequent gains of $20 \mathrm{q}, 8 \mathrm{q}, 11 \mathrm{q}, 12 \mathrm{p}$, and $17 \mathrm{q}$, and losses of $18 \mathrm{q}, 9 \mathrm{p}$, and $15 \mathrm{q}$ in pancreatic cancer. Genes Chromosomes Cancer 20: $383-391$

Mahlamaki EH, Kauraniemi P, Monni O, Wolf M, Hautaniemi S, Kallioniemi A (2004) High-resolution genomic and expression profiling reveals 105 putative amplification target genes in pancreatic cancer. Neoplasia 6: $432-439$

Missiaglia E, Blaveri E, Terris B, Wang YH, Costello E, Neoptolemos JP, Crnogorac-Jurcevic T, Lemoine NR (2004) Analysis of gene expression in cancer cell lines identifies candidate markers for pancreatic tumorigenesis and metastasis. Int J Cancer 112: 100-112

Murr MM, Sarr MG, Oishi AJ, van Heerden JA (1994) Pancreatic cancer. CA Cancer J Clin 44: $304-318$

Nowak NJ, Gaile D, Conroy JM, McQuaid D, Cowell J, Carter R, Goggins MG, Hruban RH, Maitra A (2005) Genome-wide aberrations in pancreatic adenocarcinoma. Cancer Genet Cytogenet 161: 36-50

Olshen AB, Venkatraman ES, Lucito R, Wigler M (2004) Circular binary segmentation for the analysis of array-based DNA copy number data. Biostatistics 5: $557-572$

Pinkel D, Segraves R, Sudar D, Clark S, Poole I, Kowbel D, Collins C, Kuo WL, Chen C, Zhai Y, Dairkee SH, Ljung BM, Gray JW, Albertson DG (1998) High resolution analysis of DNA copy number variation using comparative genomic hybridization to microarrays. Nat Genet 20: $207-211$

Pollack JR, Perou CM, Alizadeh AA, Eisen MB, Pergamenschikov A, Williams CF, Jeffrey SS, Botstein D, Brown PO (1999) Genome-wide analysis of DNA copy-number changes using cDNA microarrays. Nat Genet 23: $41-46$

Ried T, Heselmeyer-Haddad K, Blegen H, Schrock E, Auer G (1999) Genomic changes defining the genesis, progression, and malignancy potential in solid human tumors: a phenotype/genotype correlation. Genes Chromosomes Cancer 25: 195-204

Rozenblum E, Schutte M, Goggins M, Hahn SA, Panzer S, Zahurak M, Goodman SN, Sohn TA, Hruban RH, Yeo CJ, Kern SE (1997) Tumor-suppressive pathways in pancreatic carcinoma. Cancer Res 57: $1731-1734$

Scarpa A, Capelli P, Villaneuva A, Zamboni G, Lluis F, Accolla R, Mariuzzi G, Capella G (1994) Pancreatic cancer in Europe: Ki-ras gene mutation pattern shows geographical differences. Int J Cancer 57: 167-171

Schleger C, Arens N, Zentgraf H, Bleyl U, Verbeke C (2000) Identification of frequent chromosomal aberrations in ductal adenocarcinoma of the pancreas by comparative genomic hybridization (CGH). J Pathol 191: $27-32$

Smyth GK (2005) Limma: linear models for microarray data. In Bioinformatics and Computational Biology Solutions using $R$ and Bioconductor, Gentleman R, Carey V, Dudoit S, Irizarry R, Huber W (eds) pp 397-420. New York: Springer

Snijders AM, Nowak N, Segraves R, Blackwood S, Brown N, Conroy J, Hamilton G, Hindle AK, Huey B, Kimura K, Law S, Myambo K, Palmer J, Ylstra B, Yue JP, Gray JW, Jain AN, Pinkel D, Albertson DG (2001) Assembly of microarrays for genome-wide measurement of DNA copy number. Nat Genet 29: 263-264

Solinas-Toldo S, Lampel S, Stilgenbauer S, Nickolenko J, Benner A, Dohner H, Cremer T, Lichter P (1997) Matrix-based comparative genomic hybridization: biochips to screen for genomic imbalances. Genes Chromosomes Cancer 20: 399-407

Takahashi T, Yamashita H, Nagano Y, Nakamura T, Ohmori H, Avraham H, Avraham S, Yasuda M, Matsumoto M (2003) Identification and characterization of a novel Pyk2/related adhesion focal tyrosine kinaseassociated protein that inhibits alpha-synuclein phosphorylation. J Biol Chem 278: $42225-42233$

The R Development Core Team (2006) R: a language and environment for statistical computing. Vienna, Austria: The R Foundation for Statistical Computing ISBN 3-900051-07-0 http://www.r-project.org

Ueki T, Toyota M, Sohn T, Yeo CJ, Issa JP, Hruban RH, Goggins M (2000) Hypermethylation of multiple genes in pancreatic adenocarcinoma. Cancer Res 60: 1835-1839

Warshaw AL, Fernandez-del Castillo C (1992) Pancreatic carcinoma. N Engl $J$ Med 326: $455-465$ 